УДК 528.9

http://doi.org/10.36906/KSP-2020/03

Козелкова Е.Н., Наговицына В.Р. Нижневартовский государственный университет

г. Нижневартовск, Россия

\title{
КОНЦЕПЦИЯ СПЕЦИАЛИЗИРОВАННОЙ КАРТЫ ГИДРОЭКОЛОГИЧЕСКОГО НАЗНАЧЕНИЯ И ОСНОВНЫЕ ПРИНЦИПЫ ЕЕ ПРОЕКТИРОВАНИЯ
}

Аннотация. В статье приводится понятие специализированных карт, основные области применения специализированных карт, концепция специализированной карты гидроэкологического назначения, ее содержание, а также основные принципы ее проектирования.

Ключевые слова: специализированные карты; топографические карты; карты гидроэкологического назначения; речные бассейны; изучение водных объектов.

Вода - один из основных стратегических ресурсов каждого государства. Она обеспечивает экономическое и социальное благосостояние населения, существование флоры и фауны. Вода, с одной стороны, является важнейшим компонентом окружающей среды, а с другой - уязвимым природным ресурсом, который используется и охраняется как основа жизни человека. На территории Ханты-Мансийского автономного округа состав природных водных объектов в значительной степени формируется под воздействием антропогенной нагрузки [5]. Развитие нефтегазового комплекса породило многочисленные экологические проблемы [4]. Улучшение качества природных вод, их воспроизводство, надежность и безопасность водоснабжения зависят от разумного управления водными ресурсами, что требует соответствующего информационного обеспечения, в том числе картографического.

Для изучения водных объектов необходимо большое количество различных источников, тем не менее - оно основано на наземных сетевых наблюдениях (на станциях и постах). Однако имеющаяся информация таких наблюдений, к сожалению, не удовлетворяет современным условиям ни с точки зрения полноты, ни с точки зрения охвата территории. В условиях несовершенства фактической информации значение крупномасштабных топографических карт, создаваемых полевыми методами, обладающих наибольшей точностью и позволяющих изучать водные объекты (и их гео- и экосистемные особенности), возрастает за счет набора прямых морфометрических и косвенных географических индикаторов. Топографические карты могут обеспечить еще более высокий уровень гидроэкологических знаний территории, если их содержание набрано в заданном направлении и одновременно с основными многоцелевыми картами разработана экономичная технология создания специализированных карт.

Под специализированными картами понимаются карты не с различиями в содержании, a, как правило, с добавочным содержанием (по сравнению с топографическими) для конкретных отраслей хозяйства [7]. 
Главными отраслями использования специализированных карт стали: мелиорация, аграрное хозяйство, геологическая разведка, горнодобывающая и нефтегазодобывающая промышленность, всевозможные виды строительства, лесное хозяйство, планировка и строительство населенных пунктов. Специализированные топографические карты стали нужны в первую очередь при переходе от изыскательских работ и исследования местности к стадии выноса проектов в натуру, что и обусловило их немалые масштабы.

В таблицах условных знаков для крупномасштабных топографических карт и планов [8] выделяются объекты и свойства, наносимые на карту по дополнительным условиям для различных отраслей хозяйства, а в таблице условных знаков масштаба 1: 10000 вводится полный самостоятельный раздел «Основные аграрные угодья». Совместно стартуют мероприятия, сосредоточенные на более подробном исследовании требований к специализированным топографическим картам. Огромный охват работ в масштабах от 1: 500 до 1: 25000 выполняется для организаций Министерства мелиорации и водного хозяйства [8]. Специальные требования на картах мелиоративного назначения предъявляются к воссозданию рельефа, так как важна детальная высотная характеристика местности. Так же подробно, со всеми качественными и численными свойствами требуется демонстрировать элементы гидрографической сети. К изображению прочих топографических объектов также предъявляется ряд добавочных требований. Например, предопределять высотные отметки полотна профилированных автодорог возле всех мостов; подписывать высотные отметки дна водозаборных и водоотводных сооружений, дна подводящих и отводящих каналов у насосных станций; отметки по тальвегам и урезы воды в ручьях назначать через каждые $5 \mathrm{~cm}$.

Кроме топографических карт суши существуют топографические карты акваторий, которые разделены на карты шельфа морей и карты внутренних водоемов. К началу 1970-х гг. деятельность геолого-геофизических служб на континентальном шельфе выявила необходимость крупномасштабного непрерывного картирования шельфа с прилегающей сушей как генетически взаимозависимых частей. Карты шельфа должны охватывать полосу от морского побережья до крутого увеличения донного склона и глубин (континентальный склон).

Содержание карт шельфа, помимо компонентов содержания топографических карт суши, включает в себя изображение рельефа дна в пределах шельфа, донных отложений, информацию о свойствах и динамике водных масс, а также информацию о донной флоре и фауне. Элементы особого содержания отображаются обозначениями на самой карте, а также на диаграммах и в тексте географической информации, разбросанных по полям [2].

Для крупных озер и водохранилищ составлены топографические карты внутренних водоемов. Кроме того, их содержание должно включать изображение рельефа, донных грунтов, характеристики динамики водных систем, биологические характеристики.

Предполагается, что специализированная карта гидроэкологического назначения основана на ряде смысловых позиций. Карта, создаваемая в соответствии с ее назначением, должна отвечать задачам: анализа, изучения водных объектов и ресурсов; гидроэнергетики, строительства; оценки экологического состояния территории, определяемого водными ресурсами; систем рекреационного использования территории. Исходя из назначения карты, основные события в ее содержании относятся к изображению водных объектов и их свойств. 
Смысл специализации топографической карты заключается в изменении установленного содержания и неограниченности изображения отдельных участков при сохранении его сложности. В этом специализированная карта, остающаяся топографической по своему созданию с точки зрения математической основы, точности и целостности содержания, принципиально отличается от тематической карты.

Изменение содержания топографической карты, принимая во внимание специализацию, достигается увеличением значимости одного или нескольких компонентов для получения добавочной информации назначенного направления, а также в разгрузке содержания, не требующегося для данной отрасли. В нашем случае устанавливается задача преимущественно совершенного отображения водных объектов, учитывающего характеристику их генетических, морфологических, динамических особенностей экологического состояния, обусловленного природными процессами и антропогенным влиянием. Крупный ряд специализированных карт - от 1: 2000 до 1: 1000000.

Принимая во внимание ведущее значение речного бассейна как целой естественной экосистемы и, как следует из бассейновой стратегии управления водными ресурсами [1], предполагается два вида карт: один - в обыкновенной разграфке топографических карт, второй, гидроэкологического назначения - в планировке бассейна реки. При всем при этом содержимое карт в обеих альтернативах остается неизменным, однако их масштабы в планировке водосбора должны согласоваться с рангом бассейна. Так, бассейну небольшой реки (площадью меньше 2000 км² $^{2}$ [4] будут присвоены масштабы до 1: 200 000, бассейну средней реки (площадь 2000-50 000 км²) [4] - значение масштаба 1: 500 000, а для отражения бассейна большой реки площадью больше 50000 км$^{2}$ [4] нужны масштабы 1: 1000000 и меньше. Для сравнения можно сказать, что площади листов 1: 25 000, 1: 50 000, 1: 100 000, 1: 200000 на широте 54ㅇ одинаковы - соответственно, 76, 306, 1216, 4864 км².

Важно, что возможно составлять бассейны рек в несколько листов нужного (достаточно крупного) масштаба. Содержание специализированной карты будет состоять из надлежащей классической топографической информации и дополнительных объектов и свойств, условные обозначения которых подразумевается расположить вне рамок карт. К каждому листу либо блоку соседних листов подразумевается географическое описание справка, которой отводится огромная значимость в увеличении информативности карты и для которой изобретена особенная программа [6]. Назначение справки - дать наиболее детальный материал как о показанных на оригинале объектах, так и о тех, какие на карте показать не удалось. Эти сведения могут опровергаться в облике схем, таблиц, профилей, карт-врезок (подготовленных по иным информационным источникам, позволительно с пониженной точностью и в меньшем масштабе, чем главный оригинал) и в текстовом описании, если съемочных данных для основного оригинала оказывается слишком мало.

Водные объекты (естественные и антропогенные). Проект по картографированию природных и антропогенных водных объектов должен включать следующие разделы: берега морей и крупные озера; реки, ручьи; озера; источники; водохранилища; каналы; сооружения на водохранилищах, реках; сооружения на каналах.

Раздел «побережья морей и крупные озера» содержит понятия «побережье», «дренаж», классификацию берегов. Должны предлагаться обозначения береговой линии, направленные на отображение особенностей гидрологического режима моря, его областной динамики и миграций береговой линии, а именно: береговой линии, соответствующей среднегодовым, 
максимальным, минимальным теоретическим, критическим или экстремальным эпизодическим отметкам уровня (во время нагонов или всплесков, штормов), а также границам распространения растительности со стороны суши и моря (бесконечная береговая линия). Использование конкретного линейного знака зависит от величины обезвоживания. Специальные обозначения предусмотрены для различных типов берегов (нависание, лед, термическая абразия и т. д.) и элементов рельефа прибрежной полосы.

Среди рек и ручьев различают: постоянно-водные, сезонно-сухие, сезонно- и эпизодически-водные, а также участки рек с повременно меняющимся направлением течения (устья, в протоках между озерами и т. д.). Наибольшее число обозначений относится к свойствам постоянных водных рек, для которых указаны: длина реки и площадь бассейна, границы бассейнов крупных рек, площадь половодья и время прохождения половодья, склоны, извилистость, интенсивность русловых сдвигов и многие другие характеристики, связанные с разными фазами водного режима и приуроченные к гидрологическим постам. Должен быть предложен также ряд сведений, характеризующих экологическую напряженность речных территорий (мутность воды, места систематического образования заторов, ледяные заторы и т. д.).

Как реки, так и озера делятся на: постоянно-водные, периодически пересыхающие и сезонные. Большинство обозначений служат для отображения динамики прибрежной зоны и береговой линии, а также солености их вод, которая имеет три градации (также для родниковых) [6; 7].

Водохранилища классифицируются, в соответствии с их расположением (генезисом), на: русловые, насыпные, заблокированные лагуны и устья, по характеру регулирования речного стока (ежедневное, еженедельное, ежемесячное; сезонное; долгосрочное). Выделяются более мелкие сооружения для сбора и хранения воды (открытые, закрытые, подземные). Рассматриваются особенности каждого типа водохранилищ и характеристики объемов (полных, полезных), актуальные для проектирования и использования крупных водохранилищ; средняя глубина, назначение, площадь водной поверхности, особенности изменения объемов при различных условиях эксплуатации или в случае разрушения, отметки береговой линии на разных уровнях эксплуатации. Должны предлагаться долгосрочные средние значения баланса (обычно содержащиеся в ежегодниках): суммарные значения притоков и сбросов воды за год, которые состоят из показателей поверхностного притока (стока), осадков (испарения), сбросов (суммарного водозабора), переноса стока из других и в другие бассейны.

Каналы точно дифференцированы по назначению: судоходные; рекультивационные (орошение, коллекторно-дренажные) и приборные (в земляном русле, бетонированные, в лотках, в трубопроводах). Приводятся характеристики ширины, глубины, пропускной способности. Для судоходства - характер дна и протяженность [6].

Подробно описываются важнейшие гидротехнические сооружения на водохранилищах и реках, плотинах и водосборных сооружениях на верховьях, на каналах - регулирующие, соединительные сооружения и насосные станции, обеспечивающие бесперебойную подачу, распределение, регулирование воды в различных природных условиях.

Гидроэкологические опасности, природные памятники и контрольные точки поверхностных вод (другие компоненты локализации) [6]. Водные объекты не могут рассматриваться изолированно от взаимосвязанного комплекса компонентов природного и 
культурного ландшафта. Характерная для каждого региона природная среда - рельеф, воды, леса, луга - тесно связана с характером исторических построек, обликом населенных пунктов, экспозицией архитектурного планирования и т. д. Все это отражено на топографической карте в соответствии с ее исторически сложившимся типом. Поэтому другие составляющие содержания карты не требуют специальной специализации.

Важность географической информации для пользователей карт указывается в представлении общей информации, содержащейся в определенной научной литературе, как правило, известной близкому кругу специалистов.

Производство специализированных топографических карт является экономически выгодным и оправданным только в том случае, если они создаются в едином научнотехническом цикле с универсальными. В этом контексте сфера специализации несколько ограничена, так как необходимо и важно заботиться о сохранении типа топографической карты.

Нынешняя топографическая изученность, существование карт в цифровом варианте создают среду для изготовки специализированных карт на основе обновления ранее существующего фонда числовой информации. Следовательно, создание специализированных карт не мыслится в отсутствии сегодняшних ГИС-технологий, гарантирующих хранение, обработку и приобретение не только многоцелевых топографических, но и специализированных сведений.

Все исследования основываются на целостном подходе, где водные объекты и ресурсы характеризуются как компонентная концепция всеобщего порядка содержания топографических карт.

Карты гидроэкологического назначения будут актуальны при разработке планов и целевых программ экономического и социального развития территорий, для разработки мероприятий по охране вод, сохранению здоровья населения [7]. Исследования и анализ по теме статьи вносят вклад в развитие теории и методов топографического картографирования, являются предпосылкой для совершенствования универсальных специализированных карт.

\section{Литература}

1. Верещака Т.В., Курбатова И.Е. Оценка экологического значения водных объектов по топографическим картам // Известия высших учебных заведений. Сер. Геодезия и аэрофотосъемка. 2002. №6. С. 100-117.

2. Верещака Т.В., Вахтанов А.С. Цифровая технология обновления топографических карт масштабов 1:25 000-1:200 000 по космическим снимкам и ее концептуальные положения // Геодезия и картография. 2004. № 4. С. 33-42.

3. Государственная картографо-геодезическая служба / Под общ. ред. А.В. Бородко. М., 2004. $184 \mathrm{c}$.

4. Козелкова Е.Н., Гребенюк Г.Н. Природоохранные аспекты управления качеством водных ресурсов в бассейне Средней Оби (на примере реки Вах): Нижневартовск, 2013. 127 c.

5. Козелкова Е.Н., Жукова А.О. Анализ загрязнения природных вод донных отложений ХМАО-Югры // Культура, наука, образование: проблемы и перспективы: Материалы V Международной научно-практической конференции. Нижневартовск, 2016. С. 22. 


\section{КУЛЬТУРА. НАУКА. ОБРАЗОВАНИЕ}

6. Криволапов В.А., Верещака Т.В. Специализированная топографическая карта гидроэкологического назначения: содержание и технология создания // Известия высших учебных заведений. Сер. Геодезия и аэрофотосъемка. 2009. № 1. С. 83-90.

7. Криволапов В.А. Разработка типа специализированной топографической карты гидроэкологического назначения и технологии ее создания: Автореф. ... канд. тех. наук. М., 2008. $24 \mathrm{c}$.

8. Цветков В.Я. Классификация и типизация в геоинформатике // Известия высших учебных заведений. Сер. Геодезия и аэрофотосъемка. 2004. № 2. С. 80-87.

СКозелкова Е.Н., Наговищъына В.Р., 2020 